\title{
Familial Hypercholesterolemia in the Czech Republic: More Than 17 Years of Systematic Screening Within the MedPed Project
}

\author{
M. VRABLÍK ${ }^{1}$, M. VACLOVÁ ${ }^{1}$, L. TICHÝ ${ }^{3}$, V. SOŠKA ${ }^{4,5}$, V. BLÁHA ${ }^{6}$, L. FAJKUSOVÁ ${ }^{3}$, \\ R. ČEŠKA ${ }^{1}$, M. ŠATNÝ ${ }^{1}$, T. FREIBERGER ${ }^{2}$
}

${ }^{1}$ Third Department of Internal Medicine, General University Hospital and First Faculty of Medicine, Charles University, Prague, Czech Republic, ${ }^{2}$ Laboratory of Genetics, Centre for Cardiovascular Surgery and Transplantation, Brno, Czech Republic, ${ }^{3}$ Centre of Molecular Biology and Gene Therapy, University Hospital, Brno, Czech Republic, ${ }^{4}$ Department of Clinical Biochemistry, St. Anne's University Hospital in Brno, Czech Republic, ${ }^{5}$ Department of Laboratory Methods, Second Department of Internal Medicine, Medical Faculty, Masaryk University, Brno, Czech Republic, ${ }^{6}$ Third Department of Internal Medicine - Gerontometabolic, Medical Faculty, Charles University and University Hospital in Hradec Králové, Czech Republic

Received January 5, 2017

Accepted January 10, 2017

\begin{abstract}
Summary
Familial hypercholesterolemia (FH) is the most common autosomal dominant disorder. It is characterized by a decrease in LDL cholesterol catabolism and an early clinical manifestation of atherosclerotic vessel damage. The aim of the MedPed (Make early diagnosis to Prevent early deaths) project is an early diagnosis of $\mathrm{FH}$ patients in order to profit from early treatment and prevent cardiovascular events. Till November 30, 2016 The Czech National MedPed Database has registered 7,001 FH patients from 5,223 different families that is $17.4 \%$ of expected patients in the Czech Republic considering 1:250 FH prevalence. The improvement in diagnostic accuracy, patient cooperation and above all familial cascade screening is enabled by $\mathrm{FH}$ mutation detection using the modern technology of next-generation sequencing. FH still remain undiagnosed even though the Czech Republic is one of the most successful countries with respect to $\mathrm{FH}$ detection. The opportunities of international collaboration and experience sharing within international programs (e.g. EAS FHSC, ScreenPro $\mathrm{FH}$ etc.) will improve the detection of $\mathrm{FH}$ patients in the future and enable even more accessible and accurate genetic diagnostics.
\end{abstract}

\section{Key words}

Familial hypercholesterolemia • LDL-cholesterol • Cascade screening • MedPed

\section{Corresponding author}

T. Freiberger, Centre for Cardiovascular Surgery and Transplantation, Výstavní 17/19, 60300 Brno, Czech Republic. E-mail: tomfre@cktch.cz

\section{Introduction}

Familial hypercholesterolemia $(\mathrm{FH})$ is the most common autosomal dominant disorder. It is characterized by a decrease in LDL cholesterol catabolism and an early clinical manifestation of atherosclerotic vessel damage (Vallejo-Vaz et al. 2016). For a long time, the prevalence of heterozygous FH in the developed countries used to be reported as 1:500 (Goldstein and Brown 1973, Goldstein et al. 2001). In the light of recent studies this value was corrected to $1: 250$. Thus, we may estimate there are more than 30 million people with this disease (Benn et al. 2014, Sjouke et al. 2015). The prevalence is even higher in populations with a founder effect and, also, with a high rate of consanguine marriages, for example in Lebanon, South Africa or in Canadian Quebec. The prevalence of homozygous $\mathrm{FH}$ was corrected from the previous value 1:1.000.000 to a new one of 1:300.000 (Sjouke et al. 2015).

For the first time, FH was described in 1938 as 
familial xanthomatosis, when Müller connected familial xanthomas, high blood cholesterol level and ischemic heart disease with an inborn error of metabolism caused by a defect in one gene (Müller 1938). Next important moment in the history of FH was in 1963, when Khachadurian described heterozygous and homozygous phenotypes of FH in Lebanese patients and postulated the codominant type of inheritance (Khachadurian 1963). Ten years later, in 1973, Goldstein and Brown followed these works and described LDL receptor and its role in the catabolism of cholesterol. The defect in the LDL-receptor gene was recognized as the cause of FH (Brown and Goldstein 1973). For this discovery both the researchers were awarded the Nobel Prize in 1985.

If FH is not treated, there is much higher relative risk of early coronary events in FH patients than in the general population. Patients with homozygote FH (hoFH) typically suffer an acute cardiovascular event till 20 years of life and their life expectancy does not go beyond 30 (Huijgen et al. 2012, Cuchel et al. 2014). The situation of patients with FH improved tremendously after introducing statins on the market in 1987. A vast number of clinical studies as well as meta-analyses have proven statins are safe drugs reducing not only high concentrations of LDL-cholesterol in the circulation but, even more importantly, also the risk of cardiovascular events and cardiovascular mortality (CTT Collaboration 2010). Together with the therapeutic lifestyle changes, potent statins are treatment options of choice in $\mathrm{FH}$ patients. Particularly in this difficult-to-treat population it is frequently necessary to combine statins with other drugs such as cholesterol absorption blockers (ezetimibe) and/or bile acids sequestrants (resins). Recently, a new possibility for hypercholesterolemia treatment and (most probably, though outcome studies have not been published yet) also for the reduction of the risk of ischemic cardiovascular events - PCSK9 inhibitors have been introduced. Clinical studies in FH population confirmed high therapeutic potential and added value of treatment with PCSK9 inhibitors (Raal et al. 2015, Kastelein et al. 2015).

In spite of clinical and laboratory definition, advanced diagnostic possibilities and sufficient information of high risk of premature manifestation of atherosclerosis related to lifelong increased levels of LDL-cholesterol and, also, in spite of availability an effective lipid lowering therapy, FH still remains underdiagnosed, untreated or treated inadequately (Vallejo-Vaz et al. 2016, Nordestgaard et al. 2013).
Moreover, even using all currently available treatment options to lower LDL-C, most FH patients do not reach recommended target values (Pijlman et al. 2010, Perez de Isla et al. 2016). This holds true also for the Czech Republic, although the country belongs to the most successful countries in the detection of FH because of the systematic efforts of the MedPed project.

\section{Diagnosing familial hypercholesterolemia: so easy, so difficult}

Diagnosis of $\mathrm{FH}$ is based on a repeated measurement of serum concentrations of LDL-cholesterol (when available pre-treatment values should be considered) and a detailed family and medical history. LDL-cholesterol level above the $95^{\text {th }}$ percentile of the age and gender specific values for the population studied supports the possibility of FH diagnosis. Premature manifestation of atherosclerotic vascular complications (especially ischemic heart disease) and/or hypercholesterolemia in the proband, one of his parents, grandparents or siblings is a significant factor supporting the diagnosis of FH. Similarly, occurrence of tendon xanthomas or arcus lipoides cornae before the age of 40 years are suggestive of $\mathrm{FH}$. The concentration of triglycerides is usually normal, but higher levels do not exclude the possibility of FH diagnosis. Obviously, secondary etiology of hypercholesterolemia (e.g. hypothyroidism or nephrotic syndrome) must be ruled out. Diagnosis of FH can be confirmed by identification of a causal mutation in one of the genes, which have been recognized as causal in the development of $\mathrm{FH}-$ LDL-receptor (LDLR), apolipoprotein B (APOB), proprotein convertase subtilisin-kexin 9 (PCSK9) or some very rare variants of other genes (e.g. APOE or STAP1) (Nordestgaard et al. 2013).

Currently, the most widely accepted and, also for our conditions the most suitable diagnostic criteria of $\mathrm{FH}$ are the Dutch Lipid Clinic Network Criteria, which use point system to classify patients into categories of definite, probable, possible or unlikely diagnosis of $\mathrm{FH}$ (Van Aalst-Cohen et al. 2006). These criteria take into account the medical history (hypercholesterolemia or premature cardiovascular disease), clinical signs (xanthomas, arcus lipoides cornae before the age of 40), LDL-cholesterol or identification of a causal mutation in one of the FH-causing genes, the latter being the strongest single criterion.

The differential diagnosis of $\mathrm{FH}$ comprises 
familial combined hyperlipidemia - a polygenic disorder characterized by various lipid phenotypes, often associated with insulin resistance - or polygenic hypercholesterolemia. Severe form of heFH or hoFH can be misdiagnosed with sitosterolemia, which has an autosomal recessive type of inheritance and can be confirmed by assessment of markedly increased phytosterol concentrations in the plasma and, also, by identification of responsible mutations in the genes encoding for ABCG5 or ABCG8 transporters (Hubacek et al. 2001, Watts et al. 2014).

The increased risk of premature clinical manifestation of atherosclerosis in FH is mostly attributable to lifelong elevation of LDL-cholesterol, but there are factors significantly modifying the risk of an $\mathrm{FH}$ patient. FH patients with symptomatic or subclinical atherosclerosis, smokers, men, those initiating lipid lowering therapy at age over 40 years, patients with hypertension, diabetes or patients with high concentrations of lipoprotein (a) have increased cardiovascular disease risk compared to $\mathrm{FH}$ individuals without these characteristics (Santos et al. 2016).

\section{Molecular aspects of FH}

Most cases of FH are caused by defective gene for LDL receptor (LDLR) or apolipoprotein B-100 (APOB), rarely by a mutation in the gene for PCSK9 leading to the overproduction of this protein (gain-offunction mutations). Other mutations in genes causing $\mathrm{FH}$ phenotype have been described sporadically; these were for example gene variations in STAP1 or APOE loci (Santos et al. 2016). The phenotype of hoFH can also be caused by mutations in the LDLRAP1 gene, which are associated with an autosomal recessive form of the disease.

Only a partial correlation between the genotype and phenotype has been reported in FH subjects. Higher LDL-cholesterol and more severe phenotype are associated with so called "null mutations" in the LDLR gene, which lead to a decrease of LDLR activity below $2 \%$ of normal as compared to so called "defective mutations", in which the LDLR activity remains between 2 and $25 \%$ normal function.

Identification of a causal mutation in one of the genes responsible for the development of $\mathrm{FH}$ confirms the diagnosis of FH and thereby, also, lifelong elevation of LDL-cholesterol. Most importantly, identification of the mutation is crucial for successful cascade screening which enables unambiguous confirmation or excluding of FH in the proband's family members. Moreover, knowledge of the mutation in the family increases compliance of family members to undergo the examination, what is supported by findings from the Czech national database. In families with a known causal mutation, the number of $\mathrm{FH}$ patients per family is on average 1.77, while in families without this information it is only 1.18. More information regarding the genetic analysis of the Czech MedPed cohort can be found in the article by Tichy et al. (2017).

Recent community studies from the USA underline the benefits of genetic diagnostics as these have shown that identification of a mutation was an independent predictor of overt cardiovascular disease in hypercholesterolemic patients (Khera et al 2016). It is necessary to highlight, that a negative result of the genetic examination does not completely rule out the possibility of FH. Such a result can be caused by low sensitivity of the methods used, a position of the mutation out of the analyzed part of the gene or by a defect located in another gene. Some patients with clinical diagnosis of $\mathrm{FH}$ can have polygenic hypercholesterolemia, which is caused by multiple polymorphisms in a number of different genes. Each of these variants leads to a small increase of LDL-cholesterol and as these minor effects sum up, they may result in a marked increase of LDL-cholesterol and, thus, mimic the FH. Talmud et al. (2013) have identified 12 common variants of small effect with the largest relative contribution to LDL-cholesterol levels. Combinations of these small effect variants determine so called LDL-score, which is a measure of polygenic effect on LDL-concentrations. The value of LDL-score can help to differentiate patients with FH (low LDL-score) from patients with polygenic hypercholesterolemia (high LDL score). However, this approach needs be verified by more studies with higher number of patients. It is likely up to $30 \%$ of patients with the clinical diagnosis of FH may have polygenic hypercholesterolemia in fact (Futema et al. 2014).

Recently, the diagnostic possibilities have improved significantly with the use of next generation sequencing. In a recent study using whole-exome sequencing approach, the causal mutation was discovered in $20 \%$ of patients with definite clinical diagnosis of $\mathrm{FH}$ in whom previous DNA analysis found no mutation (Futema et al. 2014). On the other hand, targeted NGS in a cohort of hypercholesterolemic patients in a primary care setting revealed an FH-causing mutation in only $2 \%$ 
of the individuals examined (Norsworthy et al. 2014). Thus, appropriate selection of patients for the genetic analysis still remains a crucial step in FH identification.

\section{Coordinated efforts to improve FH identification: the Czech MedPed project}

The Czech Republic joined the MedPed project in 1998. However, full implementation throughout the country did not occur until the project was accepted by the Czech Society for Atherosclerosis (CSAT). A network of national and regional centers, specialized centers and professional collaborators has gradually been established under the auspices of CSAT, all of which are dedicated to identification and treatment of FH patients. Project management and coordination have been entrusted to the Centre of Molecular Biology and Gene Therapy (CMBGT) at University Hospital Brno, and, since 2003, at the Centre for Cardiovascular Surgery and Transplantation (CCST) in Brno. The clinical part of the project primarily falls under the coordination and supervision of two national centers in Prague at General University Hospital's $3^{\text {rd }}$ Internal Medicine Clinic; and in
Brno at St. Anne's University's Department of Clinical Biochemistry. Essential factors for project success include involving coordinators who ensure contact with all collaborators, and are dedicated to project promotion and database compilation.

At present, the Czech MedPed project comprises 69 active centers and collaborators. It consists of 2 adult and 2 pediatric national centers ( 2 in Prague, and 2 in Brno); 15 regional centers for adults and 10 for children; 21 specialized centers for adults and 5 for children; and additional 14 collaborating physicians. The network is dynamic - new centers are continuously being accepted to join the project, while some end their participation. All important information pertaining to project operations, its organization, and network of participating centers, can be found on the CSAT website (http://athero.cz/cze/projektmedped).

Project organization is as follows: when clinicians of different specialties (general practitioners, cardiologists, internists etc.) encounter a suspected $\mathrm{FH}$ patient, they may refer the patient to the network center. As of November 30, 2016, the database contained 7,001 registered patients from 5,223 families (Fig. 1).

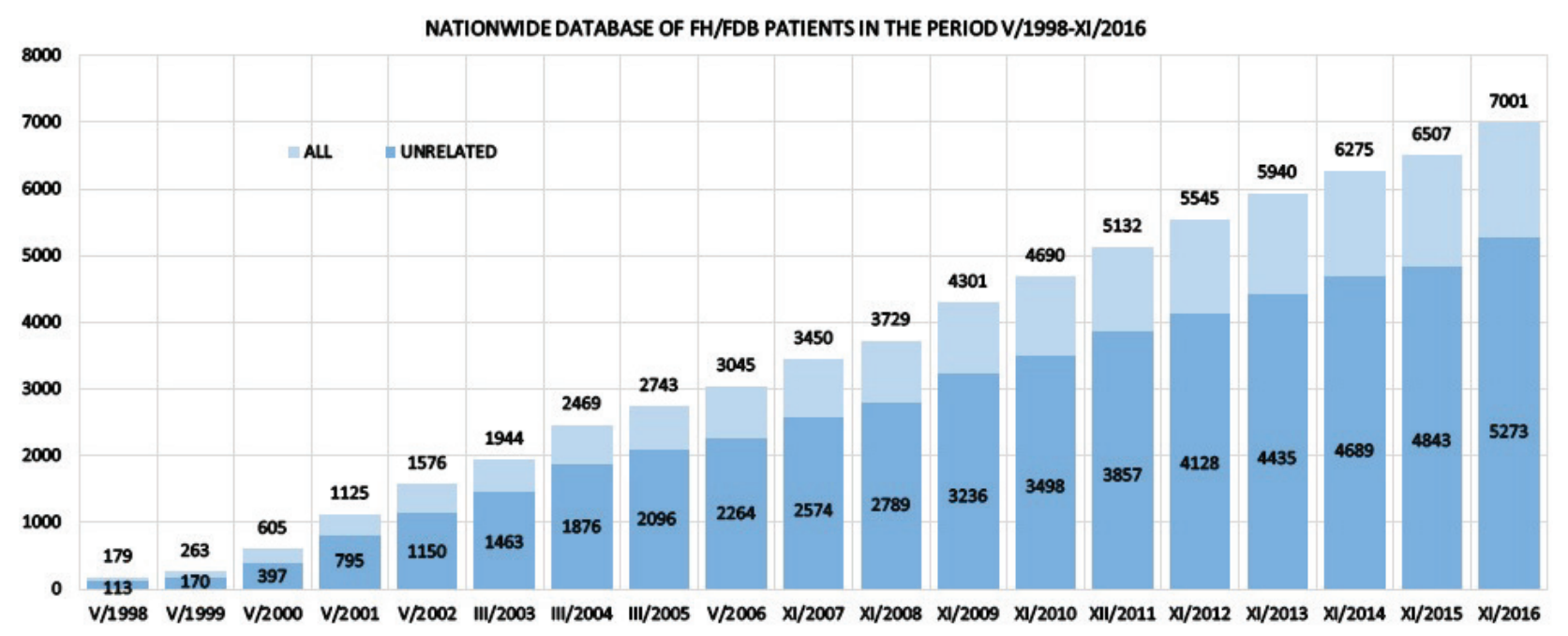

Fig. 1. Numbers of subjects included in the Czech MedPed project.

The number of patients with FH/FDB included in the database amounts to $17.4 \%$ of the estimated 40,000 patients living in the Czech Republic (when assuming the prevalence of 1:250). DNA samples were available in 4,399 unrelated patients, and mutations in the gene for the LDL receptor or $A P O B$ were found in 1,322. Moreover, the causal mutation was found in 712 pediatric patients (below the age of 18). Causal mutation in the gene for PCSK9 has not been detected in the Czech FH population. Fourteen patients with homozygous $\mathrm{FH}$ or FDB have been registered in the database.

The data are being continuously monitored and updated and as of September 1, 2016 a subset of 3067 adult patients with clinical FH was analyzed. Basic characteristics of the patients' group is given in Table 1 . The clinical and biochemical description of the patients' group according to the result of genetic analysis is provided in Table 2 . 
Table 1. Basic characteristics of a group of adult FH patients with updated records in the Czech MedPed registry as of September 1 , 2016.

\begin{tabular}{lccc}
\hline & Total & Males & Females \\
\hline$N$ & 3067 & 1107 & 1960 \\
Age (years) & $52.6 \pm 17.1$ & $48.8 \pm 16.4$ & $54.8 \pm 17.6$ \\
BMI $\left(\mathrm{kg} / \mathrm{m}^{2}\right)$ & $26.9 \pm 5.1$ & $26.3 \pm 4.8$ & $27.2 \pm 5.8$ \\
Premature atherosclerosis (\%) & 5.1 & 8.0 & 3.5 \\
T2DM (\%) & 6.8 & 6.0 & 7.3 \\
Smoking $(\%)$ & 14.1 & 14.5 & 13.7 \\
Tendon xanthomatosis $(\%)$ & 2.7 & 3.4 & 2.2 \\
Xanthelasma palpebrarum (\%) & 5.6 & 5.7 & 5.6 \\
TC $($ mmol/l $\pm S D)$ & $8.59 \pm 1.79$ & $1.8 \pm 1.52$ & $8.69 \pm 2.0$ \\
TG $($ mmol/l $\pm S D)$ & $1.69 \pm 1.33$ & $1.37 \pm 0.91$ & $1.63 \pm 1.21$ \\
HDL-C $(\mathrm{mmol} / \mathrm{l} \pm S D)$ & $1.55 \pm 0.98$ & $6.21 \pm 1.48$ & $1.65 \pm 1.18$ \\
LDL-C (mmol/l $\pm S D)$ & $6.26 \pm 1.71$ & $6.29 \pm 1.92$
\end{tabular}

BMI - body mass index, TC - total cholesterol, TG - triglycerides, HDL-C - high density lipoprotein cholesterol, LDL-C - low density lipoprotein cholesterol, T2DM - type 2 diabetes mellitus, premature atherosclerosis was defined as an atherothrombotic event in personal medical history before the age of 55 in males and before the age of 60 in females.

Table 2. Characteristics of a group of adult FH patients with updated records in the Czech MedPed registry as of September 1, 2016 according to the results of genetic analysis.

\begin{tabular}{lcccc}
\hline & All adult FH & LDLR mutation & APOB mutation & No mutation \\
\hline$N$ & 3067 & 831 & 454 & 1782 \\
Age (years $\pm S D)$ & $52.6 \pm 17.1$ & $49.9 \pm 17.1$ & $47.2 \pm 19.1$ & $56.2 \pm 16.7$ \\
BMI $\left(\mathrm{kg} / \mathrm{m}^{2} \pm S D\right)$ & $26.9 \pm 5.1$ & $26.2 \pm 4.8$ & $27.8 \pm 5.2$ & $27.0 \pm 4.7$ \\
Premature atherosclerosis (\%) & 5.1 & 5.3 & 2.9 & 5.6 \\
T2DM (\%) & 6.8 & 4.1 & 3.5 & 8.9 \\
Hypertension (\%) & 17.0 & 11.9 & 11.2 & 20.8 \\
Tendon xanthomatosis $(\%)$ & 2.7 & 5.1 & 0.7 & 2.1 \\
Xanthelasma palpebrarum (\%) & 5.6 & 7.5 & $7.81 \pm 1.45$ & $8.67 \pm 1.47$ \\
TC $($ mmol/l $\pm S D)$ & $8.59 \pm 1.80$ & $8.33 \pm 2.12$ & $1.23 \pm 1.16$ & $1.86 \pm 2.1$ \\
TG $($ mmol/l $\pm S D)$ & $1.69 \pm 1.39$ & $1.6 \pm 1.58$ & $1.57 \pm 0.41$ & $1.60 \pm 0.42$ \\
HDL-C (mmol/l $\pm S D)$ & $1.55 \pm 0.44$ & $1.44 \pm 0.42$ & $5.68 \pm 1.36$ & $6.22 \pm 1.47$ \\
LDL-C (mmol/l $\pm S D)$ & $6.26 \pm 1.74$ & $6.67 \pm 2.0$ & & 5.2 \\
\hline
\end{tabular}

BMI - body mass index, TC - total cholesterol, TG - triglycerides, HDL-C - high density lipoprotein cholesterol, LDL-C - low density lipoprotein cholesterol, T2DM - type 2 diabetes mellitus, premature atherosclerosis was defined as an atherothrombotic event in personal medical history before the age of 55 in males and before the age of 60 in females, LDLR - low density lipoproteins receptor, APOB - apolipoprotein B.

It is worth emphasizing that, with respect to the proportion of FH patients diagnosed, the Czech Republic has quite a good standing among the international community and ranks $3^{\text {rd }}$ place behind the Netherlands and Norway. The key factors for successful management of the MedPed project in the Czech Republic can be summarized as follows:
- support from professional associations;

- creation of a network of MedPed centers that covers the entire Czech Republic and is supported by a professional society (CSAT);

- use of an activity coordinator;

- access to DNA diagnostics. 


\section{Challenges and future directions}

Despite the above mentioned significant successes of the FH screening program MedPed in the Czech Republic, still approximately $83 \%$ of the predicted number of FH patients in the country have not been included in the database. Therefore, the next goal is to increase medical community awareness of $\mathrm{FH}$ and the active search for patients; this should lead to an increase in the number of diagnosed and well-managed patients, and, even more importantly, a substantial increase in the number of examined members of affected families.

Lots of initiatives focusing on FH detection have been launched recently. In Australia, Pacific and South America "Ten Countries Study" was successfully conducted by Watts et al. (2016). Another rapidly developing $\mathrm{FH}$ project creating a platform for mutual interaction of $\mathrm{FH}$ patients and health care professionals "The FH Foundation" - has been developing since 2011 in the USA (O'Brien et al. 2014). In Europe, the project "FH Studies Collaboration" led by K. Ray and supported by the European Atherosclerosis Society (EAS) has evolved into a multinational project aiming at providing a consolidated data on $\mathrm{FH}$ in the region together with creation of a universal database platform for data collection (Vallejo-Vaz et al. 2015). The ScreenProFH project, embedded in the FHSC initiative, helps to enhance FH screening activities in the region of Central, Eastern and Southern Europe as well as Central Asia and is described in detail in a separate article (Ceska et al. 2017). Czech MedPed project is actively participating at and/or collaborating with all these international activities. Undoubtedly, these coordinated international efforts should increase the chances to achieve the principal goal - to identify, diagnose and provide treatment for all $\mathrm{FH}$ patients early enough to prevent development of atherosclerotic vascular complications and avoid unnecessary premature death.

\section{Conclusion}

Familial hypercholesterolemia is the most common hereditary metabolic disease leading to early deaths due to rapid progression of atherosclerotic vascular disease. Early diagnosis and effective treatment can significantly improve the prognosis of $\mathrm{FH}$ patients. Thus, initiatives enhancing early detection and appropriate therapeutic approach in this population are vital. The Czech MedPed project has been working to the above-mentioned aims for more than 17 years. The opportunities of international collaboration and experience sharing within international programs (e.g. EAS FHSC, ScreenPro FH etc.) will improve the detection of $\mathrm{FH}$ patients in the future including more accessible and accurate genetic diagnostics.

\section{Conflict of Interest}

There is no conflict of interest.

\section{Acknowledgements}

Supported by Ministry of Health of the Czech Republic, grant nr. 15-28277A. All rights reserved. Special thanks belong to collaborating centers (list on website http://www.athero.cz/projekt-medped/proodborniky/ pracoviste-medped), project coordinators (E. Fironova, E. Mitvalska and M. Plotena), staff of genetic diagnostics laboratory (M. Slezackova and P. Zapletalova), Galen Symposion company and Mgr. Hana Stredova for help with project logistics. The Czech MedPed project has been supported by unrestricted grants from Amgen, AOP Orphan, Krka, MSD, Pfizer and Sanofi companies.

\section{References}

BENN M, WATTS GF, TYBJAERG-HANSEN A, NORDESTGAARD B: Mutations causative of familial hypercholesterolaemia: screening of 98098 individuals from the Copenhagen General Population Study estimated a prevalence of 1 in 217. Eur Heart J 37: 1384-1394, 2016.

BROWN MS, GOLDSTEIN JL: A receptor-mediated pathway for cholesterol homeostasis. Science 232: 34-47, 1986.

CESKA R, FREIBERGER T, VACLOVA M, ALEKSICOVA T, VOTAVOVA L, VRABLIK M: ScreenPro FH: from the Czech MedPed to international collaboration. ScreenPro FH is a participating project of the EAS-FHCS. Physiol Res 66 (Suppl 1): S85-S90, 2017.

CTT (CHOLESTEROL TREATMENT TRIALISTS') COLLABORATION: Efficacy and safety of more intensive lowering of LDL cholesterol: a meta-analysis of data from 170,000 participants in 26 randomised trials. Lancet 376: $1670-1681,2010$. 
CUCHEL M, BRUCKERT E, GINSBERG HN, RAAL FJ, SANTOS RD, HEGELE RA, KUIVENHOVEN JA, NORDESTGAARD BG, DESCAMPS OS, STEINHAGEN-THIESSEN E, TYBJAERG-HANSEN A, WATTS GF, AVERNA M, BOILEAU C, BORÉN J, CATAPANO AL, DEFESCHE JC, HOVINGH GK, HUMPHRIES SE, KOVANEN PT, MASANA L, PAJUKANTA P, PARHOFER KG, RAY KK, STALENHOEF AF, STROES E, TASKINEN MR, WIEGMAN A, WIKLUND O, CHAPMAN MJ: European Atherosclerosis Society Consensus Panel on Familial Hypercholesterolaemia: Homozygous familial hypercholesterolaemia: new insights and guidance for clinicians to improve detection and clinical management. A position paper from the Consensus Panel on Familial Hypercholesterolaemia of the European Atherosclerosis Society. Eur Heart J 35: 21, 2014.

FUTEMA M, PLAGNOL V, LI K, WHITTALL RA, NEIL HA, SEED M; SIMON BROOME CONSORTIUM, BERTOLINI S, CALANDRA S, DESCAMPS OS, GRAHAM CA, HEGELE RA, KARPE F, DURSTS R, LEITERSDORF E, LENCH N, NAIR DR, SORAN H, VAN BOCKXMEER FM; UK10K CONSORTIUM, HUMPHRIES SE: Whole exome sequencing of familial hypercholesterolaemia patients negative for LDLR/APOB/PCSK9 mutations. J Med Genet 51: 537-544, 2014.

GOLDSTEIN JL, BROWN MS: Familial hypercholesterolemia: identification of a defect in the regulation of 3-hydroxy-3-methylglutaryl coenzyme A reductase activity associated with overproduction of cholesterol. Proc Natl Acad Sci U S A 70: 2804-2808, 1973.

GOLDSTEIN JL, HOBBS HH, BROWN MS: Familial hypercholesterolemia. In: The Metabolic and Molecular Bases of Inherited Disease. 8th edition, SCRIVER CR, BEAUDET AL, SLY WS, VALLE D (eds), McGraw-Hill, New York, 2001, pp 2863-2914.

HUBACEK JA, BERGE KE, COHEN JC, HOBBS HH: Mutations in ATP-cassette binding proteins G5 (ABCG5) and G8 (ABCG8) causing sitosterolemia. Hum Mutat 18: 359-360, 2001.

HUIJGEN R, KINDT I, DEFESCHE JC, KASTELEIN JJ: Cardiovascular risk in relation to functionality of sequence variants in the gene coding for the low-density lipoprotein receptor: a study among 29,365 individuals tested for 64 specific low-density lipoprotein-receptor sequence variants. Eur Heart J 33: 2325-2330, 2012.

KASTELEIN JJ, GINSBERG HN, LANGSLET G, HOVINGH GK, CESKA R, DUFOUR R, BLOM D, CIVEIRA F, KREMPF M, LORENZATO C, ZHAO J, PORDY R, BACCARA-DINET MT, GIPE DA, GEIGER MJ, FARNIER M: ODYSSEY FH I and FH II: 78 week results with alirocumab treatment in 735 patients with heterozygous familial hypercholesterolaemia. Eur Heart J 36: 2996-3003, 2015.

KHACHADURIAN AK: The inheritance of essential familial hypercholesterolemia. Am J Med 37: 402-407, 1964.

KHERA AV, WON HH, PELOSO GM, LAWSON KS, BARTZ TM, DENG X, VAN LEEUWEN EM, NATARAJAN P, EMDIN CA, BICK AG, MORRISON AC, BRODY JA, GUPTA N, NOMURA A, KESSLER T, DUGA S, BIS JC, VAN DUIJN CM, CUPPLES LA, PSATY B, RADER DJ, DANESH J, SCHUNKERT H, MCPHERSON R, FARRALL M, WATKINS H, LANDER E, WILSON JG, CORREA A, BOERWINKLE E, MERLINI PA, ARDISSINO D, SALEHEEN D, GABRIEL S, KATHIRESAN S: Diagnostic yield and clinical utility of sequencing familial hypercholesterolemia genes in patients with severe hypercholesterolemia. $\mathrm{J} \mathrm{Am}$ Coll Cardiol 67: 2578-2589, 2016.

MÜLLER C: Angina pectoris in hereditary xanthomatosis. Arch Intern Med 64: 675-700, 1939.

NORDESTGAARD BG, CHAPMAN MJ, HUMPHRIES SE, GINSBERG HN, MASANA L, DESCAMPS OS, WIKLUND O, HEGELE RA, RAAL FJ, DEFESCHE JC, WIEGMAN A, SANTOS RD, WATTS GF, PARHOFER KG, HOVINGH GK, KOVANEN PT, BOILEAU C, AVERNA M, BORÉN J, BRUCKERT E, CATAPANO AL, KUIVENHOVEN JA, PAJUKANTA P, RAY K, STALENHOEF AF, STROES E, TASKINEN MR, TYBJÆRG-HANSEN A; EUROPEAN ATHEROSCLEROSIS SOCIETY CONSENSUS PANEL: Familial hypercholesterolaemia is underdiagnosed and undertreated in the general population: guidance for clinicians to prevent coronary heart disease: Consensus Statement of the European Atherosclerosis Society. Eur Heart J 34: 3478-3490, 2013.

NORSWORTHY PJ, VANDROVCOVA J, THOMAS ER, CAMPBELL A, KERR SM, BIGGS J, GAME L, SOUTAR AK, SMITH BH, DOMINICZAK AF, PORTEOUS DJ, MORRIS AD, SCOTLAND G, AITMAN TJ: Targeted genetic testing for familial hypercholesterolaemia using next generation sequencing: a populationbased study. BMC Med Genet 15: 70, 2014. 
O'BRIEN EC, ROE MT, FRAULO ES, PETERSON ED, BALLANTYNE CM, GENEST J, GIDDING SS, HAMMOND E, HEMPHILL LC, HUDGINS LC, KINDT I, MORIARTY PM, ROSS J, UNDERBERG JA, WATSON K, PICKHARDT D, RADER DJ, WILIMON K, KNOWLES JW: Rationale and design of the familial hypercholesterolemia foundation CAscade SCreening for Awareness and DEtection of Familial Hypercholesterolemia registry. Am Heart J 167: 342-349, 2014.

PEREZ DE ISLA L, ALONSO R, WATTS GF, MATA N, SALTIJERAL CEREZO A, MUÑIZ O, FUENTES F, DIAZ-DIAZ JL, DE ANDRÉS R, ZAMBÓN D, RUBIO-MARIN P, BARBA-ROMERO MA, SAENZ P, SANCHEZ MUÑOZ-TORRERO JF, MARTINEZ-FAEDO C, MIRAMONTES-GONZALEZ JP, BADIMÓN L, MATA P; SAFEHEART INVESTIGATORS: Attainment of LDL-cholesterol treatment goals in patients with familial hypercholesterolemia: 5 - year SAFEHEART Registry follow-up. J Am Coll Cardiol 67: 1278$1285,2016$.

PIJLMAN AH, HUIJGEN R, VERHAGEN SN, IMHOLZ BP, LIEM AH, KASTELEIN JJ, ABBINK EJ, STALENHOEF AF, VISSEREN FL: Evaluation of cholesterol lowering treatment of patients with familial hypercholesterolemia: a large cross-sectional study in the Netherlands. Atherosclerosis 209: 189-194, 2010.

RAAL FJ, STEIN EA, DUFOUR R, TURNER T, CIVEIRA F, BURGESS L, LANGSLET G, SCOTT R, OLSSON AG, SULLIVAN D, HOVINGH GK, CARIOU B, GOUNI-BERTHOLD I, SOMARATNE R, BRIDGES I, SCOTT R, WASSERMAN SM, GAUDET D; RUTHERFORD-2 INVESTIGATORS: PCSK9 inhibition with evolocumab (AMG 145) in heterozygous familial hypercholesterolaemia (RUTHERFORD-2): a randomised, double-blind, placebo-controlled trial. Lancet 385: 331-340, 2015.

SANTOS RD, GIDDING SS, HEGELE RA, CUCHEL MA, BARTER PJ, WATTS GF, BAUM SJ, CATAPANO AL, CHAPMAN MJ, DEFESCHE JC, FOLCO E, FREIBERGER T, GENEST J, HOVINGH GK, HARADASHIBA M, HUMPHRIES SE, JACKSON AS, MATA P, MORIARTY PM, RAAL FJ, AL-RASIDI K, RAY KK, REINER Z, SIJBRANDS EJ, YAMASHITA S: International Atherosclerosis Society Severe Familial Hypercholesterolemia Panel: Defining severe familial hypercholesterolaemia and the implications for clinical management: a consensus statement from the International Atherosclerosis Society Severe Familial Hypercholesterolemia Panel. Lancet Diabetes Endocrinol 4: 850-861, 2016.

SJOUKE B, KUSTERS DM, KINDT I, BESSELING J, DEFESCHE JC, SIJBRANDS EJ, ROETERS VAN LENNEP JE, STALENHOEF AF, WIEGMAN A, DE GRAAF J, FOUCHIER SW, KASTELEIN JJ, HOVINGH GK: Homozygous autosomal dominant hypercholesterolaemia in the Netherlands: prevalence, genotype-phenotype relationship, and clinical outcome. Eur Heart J 36: 560-565, 2015.

TALMUD PJ, SHAH S, WHITTALL R, FUTEMA M, HOWARD P, COOPER JA, HARRISON SC, LI K, DRENOS F, KARPE F, NEIL HA, DESCAMPS OS, LANGENBERG C, LENCH N, KIVIMAKI M, WHITTAKER J, HINGORANI AD, KUMARI M, HUMPHRIES SE: Use of low-density lipoprotein cholesterol gene score to distinguish patients with polygenic and monogenic familial hypercholesterolaemia: a case-control study. Lancet 381: 1293-1301, 2013.

TICHY L, FAJKUSOVA L, ZAPLETALOVA P, SCHWARZOVA L, VRABLIK M, FREIBERGER T: Molecular genetic background of an autosomal dominant hypercholesterolemia in the Czech Republic. Physiol Res 66 (Suppl 1): S47-S54, 2017.

VALLEJO-VAZ AJ, KONDAPALLY SR, COLE D, HOVINGH GK, KASTELEIN JJ, MATA P, RAAL FJ, SANTOS RD, SORAN H, WATTS GF, ABIFADEL M, AGUILAR-SALINAS CA, AKRAM A, ALNOURI F, ALONSO R, AL-RASIDI K, BANACH M, BOGSRUD MP, BOURBON M, BRUCKERT E, CAR J, CORRAL P, DESCAMPS O, DIEPLINGER H, DURST R, FREIBERGER T, GASPAR IM, GENEST J, HARADA-SHIBA M, JIANG L, KAYIKCIOGLU M, LAM CS, LATKOVSKIS G, LAUFS U, LIBEROPOULOS E, NILSSON L, NORDESTGAARD BG, O'DONOGHUE JM, SAHEBKAR A, SCHUNKERT H, SHEHAB A, STOLL M, SU TC, SUSEKOV A, WIDÉN E, CATAPANO AL, RAY KK: Familial hypercholesterolaemia: a global call to arms. Atherosclerosis 243: 257-259, 2015.

VAN AALST-COHEN ES, JANSEN AC, TANCK MW, DEFESCHE JC, TRIP MD, LANSBERG PJ, STALENHOEF AF, KASTELEIN JJ: Diagnosing familial hypercholesterolaemia: the relevance of genetic testing. Eur Heart $J$ 27: 2240-2246, 2006. 
WATTS GF, GIDDING S, WIERZBICKI AS, TOTH PP, ALONSO R, BROWN WV, BRUCKERT E, DEFESCHE J, LIN KK, LIVINGSTON M, MATA P, PARHOFER KG, RAAL FJ, SANTOS RD, SIJBRANDS EJ, SIMPSON WG, SULLIVAN DR, SUSEKOV AV, TOMLINSON B, WIEGMAN A, YAMASHITA S, KASTELEIN JJ: Integrated guidance on the care of familial hypercholesterolaemia from the International FH Foundation. Int J Cardiol 171: 309-325, 2014.

WATTS GF, DING PY, GEORGE P, HAGGER MS, HU M, LIN J, KHOO KL, MARAIS AD, MIIDA T, NAWAWI HM, PANG J, PARK JE, GONZALEZ-SANTOS LB, SU TC, TRUONG TH, SANTOS RD, SORAN H, YAMASHITA S, TOMLINSON B: Translational research for improving the care of familial hypercholesterolemia: the "Ten Countries Study" and beyond. J Atheroscler Thromb 23: 891-900, 2016. 